\title{
KESADARAN HUKUM MASYARAKAT TERHADAP PERKAWINAN DIBAWAH UMUR DITINJAU DARI UNDANG-UNDANG NO. 16 TAHUN 2019 TENTANG PERUBAHAN UNDANG-UNDANG NO. 1 TAHUN 1974 TENTANG PERKAWINAN
}

\author{
Neng Hilda Febriyanti ${ }^{1}$, Anton Aulawi ${ }^{2}$ \\ Universitas Banten Jaya \\ Serang, Indonesia \\ nenghildafebriyanti@gmail.com ${ }^{1}$, antonaulawi@unbaja.ac.id ${ }^{2}$
}

\begin{abstract}
This study aims to determine the level of legal awareness of the community in Pamengkang Village, Kramatwatu District, Serang Regency about underage marriage in terms of Law No. 16 of 2019 concerning Amendments to Law No. 1 of 1974 concerning Marriage. The approach used in this study is a qualitative approach. Qualitative research is research that describes, describes what is seen, heard, felt, and asked. The data collection techniques that will be carried out by researchers in this study are structured observation, interviews and documentation. The results of this study are that underage marriages in Pamengkang Village, Kramatwatu District, Serang Regency are still occurring due to several factors, namely, traditional factors or local customs, concerns about community gossip when their daughter becomes an old maid (late in marriage) if not married at a young age, weak economic factors, unemployment, low education and school dropouts. This shows that the Pamengkang Village Community is not aware of the law or the level of awareness and legal compliance is still low, especially awareness of the age limit for marriage as regulated in the Marriage Law by not having an underage marriage. Factors that contribute to the lack of awareness and legal compliance of the Pamengkang Village community with the Marriage Law and not having underage marriages are due to factors of education, habit of disobeying the law and lack of socialization and legal counseling of the Marriage Law and the risks of underage marriage by the Government concerned. .
\end{abstract}

Keywords: legal awareness, underage marriage

\section{PENDAHULUAN}

Pernikahan di Indonesia telah diatur oleh negara, dalam hal ini negara memberikan perhatian sekaligus memiliki tanggung jawab dalam mengontrol serta memberikan pengarahan mengenai perkawinan yang merupakan Institusi sosial dalam melindungi dan menjunjung harga diri perempuan. Oleh sebab itu, Negara dan Pemerintah membuat peraturan mengenai batas usia minimal seseorang dalam melaksanakan pernikahan. Oleh sebab itu, Negara dan Pemerintah membuat peraturan mengenai batas usia minimal seseorang dalam melaksanakan pernikahan. (Achmad Bahroni dkk; 33:2019)

Perkawinan adalah ikatan lahir batin antara seorang pria dengan seorang wanita sebagai suami istri”. (Pasal 1 No. Undang-Undang No.1 Tahun 1974 tentang Perkawinan). Sedangkan tujuan dari perkawinan tersebut, menurut Pasal 1 Undang-Undang No.1 Tahun 1974 tentang Perkawinan (untuk selanjutnya disebut Undang-Undang Perkawinan), bahwa tujuan perkawinan adalah untuk 
membentuk keluarga/rumah tangga yang bahagia dan kekal berdasarkan Ketuhanan Yang Maha Esa. Maka untuk mencapai tujuan perkawinan tersebut dibutuhkan persiapan yang matang sebelum melangsungkan perkawinan/pernikahan, termasuk didalamnya adalah usia yang matang untuk menikah.

Perkawinan/Pernikahan yang dimaksud disini adalah perkawinan yang dicatat secara resmi oleh Pemerintah. Menurut Neng Djubaidah, yang dimaksud dengan "pencatatan perkawinan" adalah pencatatan atas perkawinan yang sah menurut Hukum Islam, yaitu perkawinan yang memenuhi rukun dan syarat perkawinan sesuai syariah Islam yang dilakukan di KUA setempat. Adapun yang dimaksud "perkawinan tidak tercatat" adalah perkawinan yang sah sesuai syariat (hukum) Islam yang belum didaftarkan, sehingga belum tercatat di KUA setempat.( Neng Djubaidah, 2012:3 dalam Ani Yumarni dan Endeh Suhartini; 2019:196).

Selain persoalan pencatatan perkawinan yang diatur oleh UU Nomor 1 Tahun 1974, persoalan batasan minimal usia bagi calon pasangan yang akan menikah masih menjadi permasalahan hampir di sebagian besar wilayah di Indonesia yang disebabkan oleh berbagai alasan. Fenomena ini dikenal dengan perkawinan bawah umur atau nikah dini. Hal ini juga terkendala dengan kewenangan pengawasan administrasi pencatatan perkawinan, yaitu dilakukan oleh Pejabat Pencatat Nikah (PPN) yang berada pada setiap Kantor Urusan Agama (KUA) di wilayah Kecamatan. Sebagaimana ketentuan Pasal 2 Peraturan Menteri Agama Nomor 11 Tahun 2007 tentang Pencatatan Nikah, PPN adalah selaku Pejabat yang melakukan pemeriksaan persyaratan, pengawasan, dan pencatatan peristiwa nikah/rujuk, pendaftaran cerai talak, cerai gugat, dan melakukan bimbingan perkawinan. Terhadap calon pasangan perkawinan Bawah Umur, PPN berperan sebagai lembaga yang mewujudkan tertib administrasi pencatatan perkawinan dengan mengharuskan adanya dokumen penetapan Pengadilan tentang Dispensasi Kawin bagi Calon pasangan bawah umur dimaksud, yang selanjutnya dapat dicatatkan oleh PPN setempat.( Ani Yumarni dan Endeh Suhartini; 2019:197)

Seiring dengan perkembangan zaman, maka ketentuan usia perkawinan di Indonesia yang ada dalam Undang-undang Nomor 1 Tahun 1974 perlu disesuaikan lagi. Maka dipandang sangat perlu untuk melakukan upaya-upaya pembaharuan usia perkawinan di Indonesia. Bermula dari keluarnya Undang-Undang Nomor 35 Tahun 2014 tentang perubahan atas Undang-undang Nomor 23 tahun 2002 tentang Perlindungan Anak, dalam pasal 1 
ayat (1) yang dimaksud dengan anak adalah seseorang yang belum berusia 18 (delapan belas) tahun, termasuk anak yang masih dalam kandungan. (Tim Penyusun, Himpunan Peraturan Perundang-undangan Republik Indonesia Undang-undang Perlindungan Anak, 2018: 78, dalam Hotmartua Nasution, 2019:6 ).

Maka dengan itu lahirlah UndangUndang perkawinan yang diperbaharui, yang mengatur ulang batas minimal usia untuk menikah. Batas minimal usia perkawinan, yang semula diatur oleh Undang-Undang No.1 Tahun 1974, yaitu bagi pria minimal berusia 19 tahun sedangkan wanita berusia 16 tahun. Hal ini telah disebutkan didalam pasal 7 ayat (1) Undang-Undang Perkawinan, bahwa "Perkawinan hanya diizinkan bila piha pria mencapai umur 19 (sembilan belas) tahun dan pihak wanita sudah mencapai usia 16 (enam belas) tahun.", akan tetapi kemudian ketentuan pasal 7 ayat (1) tersebut dirubah dengan Undang-Undang Perkawinan yang baru yaitu UndangUndang Republik Indonesia No. 16 tahun 2019 tentang Perubahan atas UndangUndang No. 1 tahun 1974 tentang Perkawinan (untuk selanjutnya disebut Undang-Undang

Perkawinan

Perubahan/Baru), sehingga berbunyi sebagai berikut "perkawinan hanya diizinkan apabila pria dan wanita sudah mencapai umur 19 (sembilan belas) tahun".

Dijelaskan pula dalam penjelasan pasal 7 ayat (1) Undang-Undang Perkawinan yang baru tersebut, yaitu:

"Perubahan Norma dalam UndangUndang Nomor 1 tahun 1974 tentang Perkawinan ini menjangkau batas usia untuk melakukan perkawinan bagi wanita. Dalam hal ini batas minimal umur perkawinan bagi pria, yaitu 19 (sembilan belas) tahun. Batas usia dimaksud dinilai telah matang jiwa raganya untuk dapat melangsungkan perkawinan agar dapat mewujudkan tujuan perkawinan secara baik tanpa berakhir pada perceraian dan mendapat keturunan yang sehat dan berkualitas. Diharapkan juga kenaikkan batas umur yang lebih tinggi dari 16 (enam belas) tahun bagi wanita untuk kawin akan mengakibatkan laju kelahiran yang lebih rendah dan menurunkan resiko kematian ibu dan anak. Selain itu juga dapat terpenuhinya hak-hak anak sehingga mengoptimalkan tumbuh kembang anak termasuk pendampingan orang tua serta memberikan akses anak terhadap pendidikan setinggi mungkin".

Menurut data Badan Pusat Statistik (BPS) tahun 2007, angka perkawinan anak diatas 10 persen merata tersebar diseluruh provinsi Indonesia. Sementara, sebaran angka perkawinan anak diatas 25 persen berada di 23 provinsi dari 34 provinsi di Indonesia. Jika diakumulasi, 67 persen wilayah di Indonesia darurat perkawinan anak. Tiga provinsi yang memiliki persentase perkawinan anak tertinggi di Indonesia adalah Provinsi Kalimantan Selatan, Kalimantan Tengah, dan 
Kepulauan Bangka Belitung. Angkanya diatas 37 persen.(Luthfia Ayu Azanella:2018).

Pernikahan seseorang yang belum mencukupi umur tetap bisa dilaksanakan dengan syarat apabila Wali dan Pengadilan Agama telah memberikan izin Permohonan izin untuk menikah dibawah umur yang diajukan kepada Pengadilan Agama dinamakan Dispensasi Kawin. sesuai ketetapan Pasal 7 ayat (2) jis Pasal 63 UU No. 1 Tahun 1974, Pasal 49 huruf (a) UU Nomor 7 Tahun 1989 yang telah diubah dengan UU Nomor 3 Tahun 2006 dan perubahan kedua dengan UU Nomor 50 Tahun 2009, Dispensasi kawin secara absolut memang menjadi kompetensi Pengadilan Agama. (Achmad Bahroni dkk; $35: 2019)$

Anak (khususnya) perempuan akan mengalami beberapa konsekuensi dari perkawinan dibawah umur. Pertama, hilang atau terampasnya hak seorang anak. Hak-hak itu antara lain hak memperoleh pendidikan, hak untuk bermain dan hak kesehatan organ reproduksinya. Berkaitan dengan hilangnya hak kesehatan reproduksi, seorang anak yang menikah dibawah umur memiliki resiko kematian saat melahirkan yang lebih tinggi dibandingkan dengan wanita yang sudah cukup umur. Resiko ini bisa mencapai lima kali lipatnya. Selanjutnya, seorang anak perempuan yang menikah dini akan mengalami sejumlah persoalan psikologis seperti cemas, depresi, dan yang paling parah adalah keinginan untuk bunuh diri akibat belum siap untuk berumah tangga menjadi seorang isteri. Di usia yang masih dibawah umur. Seorang anak yang menikah, pengetahuan seksualitas yang masih rendah sehingga berpotensi meningkatkan resiko terkena penyakit kelamin menular seperti HIV.

Satu hal yang juga harus menjadi perhatian bersama adalah mengedepankan kepentingan terbaik bagi anak dalam memberikan hak pendidikan, hak tumbuh kembang, hak bermain, hak mendapatkan perlindungan dari kekerasan, segala bentuk eksploitasi, dan diskriminasi. Serta yang paling penting adalah menempatkan posisi anak pada dunia anak itu sendiri untuk berkembang sesuai dengan usia perkembangan anak. Oleh karena itu, ditentukan batas usia untuk melaksanakan perkawinan yaitu 19 tahun bagi pria dan wanita. Bahkan idealnya perkawinan itu dilakukan pada usia sekitar 25 tahun bagi pria dan 20 tahun bagi wanita. Namun demikian dalam keadaan yang sangat memaksa (darurat), perkawinan dibawah umur minimum sebagaimana ditentukan dalam Undang-Undang Perkawinan tersebut dimungkinkan setelah memperoleh dispensasi dari pengadilan atas permintaan orang tua. Namun 
kenyataan masih banyak yang terjadi kasus perkawinan.

Resiko dan dampak lain dari pernikahan dibawah umur juga akan adalah terhadap anak-anak yang nantinya lahir dari hubungan kedua orangtuanya yang menikah di bawah umur. Belum matangnya usia ibu muda dari perkawinan tersebut, mendatangkan resiko pada si calon anak. Misalnya, angka risiko kematian bayi lebih besar. Sedangkan dampak yang terjadi di masyarakat, di antaranya adalah berpotensi menciptakan angka kemiskinan baru. Hal itu terjadi karena pernikahan dini biasanya tidak dibarengi dengan tingginya tingkat pendidikan dan kemampuan finansial. Hal itu juga akan berpengaruh besar terhadap cara didik orangtua yang belum matang secara usia kepada anak-anaknya. Pada akhirnya, berbuntut siklus kemiskinan yang berkelanjutan atau yang lebih parah lagi adalah rentan terjadi perceraian akibat faktor ekonomi tersebut.

Undang-undang perkawinan ini menganut azas kemantangan calon mempelai, bahwa calon suami istri itu harus telah masak jiwa raganya untuk dapat melangsungkan perkawinan, agar dapat mewujudkan tujuan perkawinan secara baik tanpa berakhir pada perceraian dan mendapat keturunan yang baik dan sehat. (Ibnu Radwan Siddiq T, 2019: 40.)
Untuk itu harus dicegah adanya perkawinan antara calon suami istri yang masih dibawah umur. Disamping itu, perkawinan mempunyai hubungan dengan masalah kependudukan. Ternyatalah bahwa batas umur yang lebih rendah bagi seorang wanita untuk kawin mengakibatkan laju kelahiran yang lebih tinggi. (Hotmartua Nasution, 2019:55)

Gambaran kasus-kasus/perkara cerai gugat di Pengadilan Agama Serang (cerai gugat dalam istilah hukum acara Pengadilan Agama berarti gugatan cerai yang diajukan oleh pihak isteri, jika yang mengajukan pihak suami istilahnya adalah cerai talak) yang terjadi akibat terjadinya penelantaran keluarga dengan sampel kasus sebanyak 20 kasus/perkara dengan rincian, 10 perkara perceraian pada tahun 2017, dan 10 perkara perceraian pada tahun 2018 untuk ditelaah. Berdasarkan hasil telaah, kasus-kasus perceraian yang dilatarbelakangi oleh masalah ekonomi berupa penelantaran keluarga meliputi pengabaian nafkah keluarga, meninggalkan isteri tanpa kabar berita, malas bekerja, pelit (member nafkah belanja semaunya tanpa memperhatikan banyaknya kebutuhan hidup) dan menyuruh isteri bekerja keras bahkan sampai menjadi TKI ke luar negeri sedangkan suami tidak bekerja, menempati urutan pertama sebagai alasan/penyebab terjadinya gugat cerai. (Anton Aulawi. 2018:55) 
Oleh sebab itu, dengan tingginya angka pernikahan dini sebagaimana data yang dikemukakan diatas dan berpengaruh pula terhadap angka perceraian yang di Pengadilan Agama, maka urgen untuk diteliti tentang relasi perkawinan di bawah umur dengan resikonya khususnya terhadap perempuan, seperti resiko melahirkan diusia muda, masalah kesejahteraan keluarga, dan potensi perceraian. Relasi antara perkawinan bawah umur tersebut dihubungkan dengan kesadaran hukum masyarakat setempat yaitu di Desa Pamengkang dan peran dan kewenangan PPN setempat. Hal tersebut ditujukan untuk menilai apakah upaya administratif dapat mengurangi pernikahan bawah umur beserta resikonya.

Untuk itu Peneliti ingin mengetahui lebih jauh mengenai kesadaran dan kepatuhan hukum di Desa Pamengkang terkait, Kesadaran Hukum Masyarakat Terhadap Perkawinan Dibawah Umur Ditinjau Dari Undang-Undang No. 16 Tahun 2019 Tentang Perubahan UndangUndang No. 1 Tahun 1974 Tentang Perkawinan Di Desa Pamengkang, Kecamatan Kramatwatu, Kabupaten Serang.

\section{METODE PENELITIAN}

Penelitian ini dilaksanakan di Desa Pamengkang, Kecamatan Kramatwatu, Kabupaten Serang.
Pendekatan yang digunakan dalam penelitian ini adalah pendekatan kualitatif. Penelitian kualitatif adalah penelitian yang menggambarkan, mendeskripsikan dengan apa yang dilihat, didengar, dirasakan, dan ditanyakan. (Sugiyono, 2016:49)

Adapun teknik pengumpulan data yang akan dilakukan peneliti pada penelitian ini adalah sebagai:

a) Observasi Terstruktur

Dalam penelitian ini Peneliti mengumpulkan data dengan melakukan penelitian langsung ke lokasi penelitian yang telah direncanakan sebelumnya tentang apa yang akan diamati. observasi terstruktur dilakukan apabila peneliti sudah ada kepastian tentang variable yang akan diamati dengan menggunakan instrument penelitian yang telah teruji. (Sugiyono, 2016:146)

b) Wawancara

Peneliti akan melakukan
wawancara dengan pedoman
wawancara yang sudah dibuat kepada informan secara lisan dan tulisan. Informan di sini adalah warga masyarakat di Desa Pamengkang, Kecamatan Kramatwatu, Kabupaten Serang. Dalam hal ini Peneliti akan memberikan pertanyaan-pertanyaan yang sudah disusun dalam pedoman wawancara yang terstruktur, sehingga jawaban yang diperoleh dari 
Narasumber lengkap dan sesuai yang dibutuhkan.

c) Dokumentasi

Peneliti akan melakukan dokumentasi untuk mencari data mengenai hal-hal yang berkaitan dengan variabel yang berupa catatan, arsip, dan agenda lainnya yang dapat mendukung tim dalam penelitian. Dalam pengecekan data peneliti menggunakan teknik pemeriksaan keabsahan data yaitu triangulasi. Triangulasi merupakan teknik pemeriksa keabsahan data yang memanfaatkan sesuatu yang lain. Di luar data itu keperluan pengecekan atau sebagai pembanding terhadap data itu. (Lexy J. Moleong, 2014 : 330).

Analisis data yang digunakan dalam penelitian ini adalah analisis data kualitatif, karena data yang sudah dikumpulkan dengan melakukan analisis dan kemudian dipaparkan secara deskriptif (uraian), guna mendapatkan hasil dan kesimpulan. Data disebut kualitatif karena data yang diperoleh merupakan informasi naratif bukan berupa angka namun data tersebut adalah detail, terperinci.

Analisis data dalam penelitian ini dilakukan melalui tiga kegiatan yang terjadi secara bersamaan yaitu reduksi data, penyajian data, dan penarikan kesimpulan atau verifikasi (Sugiyono, 2016:334).

Berdasarkan langkah-langkah tersebut, maka dalam penelitian ini pada tahap awal setelah diadakan pengumpulan data melalui teknik wawancara dengan berbagai sumber data yang dianggap mengetahui tentang Kesadaran Hukum terhadap Perkawinan dibawah umur ditinjau dari UndangUndang No. 16 tahun 2019 tentang Perubahan Undang-Undang No. 1 tahun 1974 tentang Perkawinan di Desa Pamengkang, Kecamatan Kramatwatu, Kabupaten Serang. Selain itu dikumpulkan pula hasil observasi dan dokumentasi yang diperoleh sesuai dengan rumusan masalah dalam penelitian ini. Data-data telah terkumpul dan dipilah-pilah sesuai dengan permasalahan yang diteliti, kemudian disajikan dalam bentuk naratif atau dideskriptifkan secara gamblang yang sebenarnya yang ditemui dari hasil penelitian penyajian data tersebut disajikan.

\section{PEMBAHASAN}

Kesadaran Hukum Masyarakat Desa Pamengkang Terhadap Resiko Perkawinan Di Bawah Umur ditinjau dari Undang-Undang No. 16 Tahun 2019 Tentang Perubahan Undang- 
Undang No. 1 Tahun 1974 Tentang Perkawinan.

Kesadaran hukum menurut Beni Ahmad Saebeni (2006:197) artinya keadaan ikhlas yang muncul dari hati nurani dalam mengakui dan mengamalkan sesuatu sesuai dengan tuntunan yang terdapat di dalamnya, yang muncul dari hati nurani dan jiwa yang terdalam dari manusia sebagai individu atau masyarakat untuk melaksanakan pesan-pesan yang terdapat dalam hukum".

Menurut Soerjono Soekanto (2017:159) ada empat unsur kesadaran hukum yaitu:

1) Pengetahuan tentang hukum,

2) Pengetahuan tentang isi hukum,

3) Sikap hukum,

4) Pola Perilaku Hukum.

Di Indonesia masalah kesadaran hukum mendapat tempat yang sangat penting dalam politik hukum khususnya, serta dalam pembangunan pada umumnya yang merupakan suatu perubahan yang direncanakan.

Paham kesadaran hukum sebenarnya berkisar pada diri warga masyarakat yang menjadi faktor penentu bagi keabsahan suatu hukum. Pada awalnya masalah kesadaran hukum timbul dalam proses penerapan dari suatu hukum positif yang tertulis. Namun, di dalam kerangka proses tersebut timbul suatu masalah, sehingga memunculkan ketidaksesuaian antara dasar keabsahan hukum yakni pengendalian sosial dari penguasa dan kesadaran hukum masyarakat dengan kenyataan-kenyataan dipatuhi atau tidak dipatuhinya hukum positif tersebut. (Ahmad Tholabi Kharlie; 2008:122).

Dapat disimpulkan bahwa dari hasil temuan penelitian berupa wawancara dan observasi di lapangan dalam hal ini berlokasi di Desa Pamengkang, Kecamatan Kramatwatu, Kabupaten Serang bahwa kesadaran dan kepatuhan hukum masyarakat tentang Undang-Undang Perkawinan khususnya batasan umur untuk melakukan perkawinan/pernikahan masih kurang.

Dimana batasan umur untuk bisa menikah dijelaskan dalam pasal 7 ayat (1) Undang-Undang Republik Indonesia No. 16 tahun 2019 tentang Perubahan atas Undang-Undang No. 1 tahun 1974 tentang Perkawinan yang berbunyi sebagai berikut "perkawinan hanya diizinkan apabila pria dan wanita sudah mencapai umur 19 (sembilan belas) tahun".

Undang-Undang Perkawinan masih belum dipahami oleh masyarakat khsususnya para remaja yang belum cukup umur. Peneliti menemukan masih banyak masyarakat yang tidak mengetahui fungsi atau hal-hal yang diatur dalam Undang-Undang 
Perkawinan. Dari Undang-Undang Perkawinan, warga masyarakat yang menjadi pelaku perkawinan dibawah umur di desa Pamengkang menganggap bahwa undang-undang tersebut sebagai pajangan saja (diatas kertas) yang dalam implementasinya adalah tidak berlaku di masyarakat. Adapun warga masyarakat yang akan menikah, maka mereka hanya mengikuti persyaratan yang dianjurkan oleh Pegawai Pencatat Nikah (P2N) dan pihak KUA Kecamatan Kramatwatu. Berbicara mengenai Undang-Undang Perkawinan maka sebagian masyarakat di desa Pamengkang tidak mengetahui isi pasalpasal yang mengatur tentang batasan umur untuk menikah dan konsekuensinya jika melaksanakan pernikahan dibawah umur. Apalagi mengenai pelanggaran terhadap undang-undang lain yang terkait dengan perkawinan dibawah umur seperti Undang-undang Nomor 35 Tahun 2014 tentang Perubahan Atas UndangUndang Nomor 23 Tahun 2002 tentang Perlindungan Anak.

Warga masyarakat di Desa Pamengkang yang melakukan pernikahan dibawah umur, tidak selalu mendapatkan masalah atau menderita dalam rumah tangganya, bahkan mayoritas merasa bahagia dengan pernikahanya yang dilakukan saat masih muda (dibawah umur), karena mereka mendapatkan pasangan hidup yang bisa membahagiakan mereka dan bertanggungjawab. Walaupun ketika menikah mereka masih dibawah umur, namun hal tersebut tidak membuat mereka putus asa ketika mengalami permasalahan dalam rumah tangga, sehingga tidak berujung kepada perceraian.

Berdasarkan wawancara dengan salah satu informan yaitu inisial NJ selaku remaja yang melakukan perkawinan dibawah umur, NJ menikah pada usia 16 (enam belas) tahun yang sampai sekarang perkawinan tersebut masih berlangsung. Menurut NJ faktor yang menyebabkannya tetap yakin untuk menikah muda adalah karena tidak ingin lama-lama berpacaran tanpa ikatan yang jelas. Kekurangan dan hambatan yang dialami pada saat menikah muda, sudah siap NJ hadapi, baik dalam faktor materi maupun perilaku pasangan. Namun hal itu tidak membuatnya pesimis untuk berumah tangga, yang penting menurutnya ketika sudah menikah maka suami dan isteri harus sama-sama bertanggujawab atas terhadap kewajibanya masing-masing.

Kelebihan menikah muda menurut $\mathrm{NJ}$ adalah mereka memiliki kesempatan yang banyak untuk merawat anak pada usianya yang masih 
muda. Ketika menikah muda, anak-anak sudah besar dan orang tuanya masih tergolong belum tua untuk bisa bekerja menafkahi anak-anaknya.

Sedangkan hambatan yang dialami NJ dan informan lainnya adalah ketika sudah menikah maka mereka sudah tidak bisa memiliki kebebasan untuk bermain seperti layaknya seorang anak remaja, termasuk untuk berkumpul bareng teman, kalaupun ada waktu untuk berkumpul dengan teman, waktunya terbatas.

Aturan-aturan menikah yang ada dalam Undang-Undang Perkawinan dan Peraturan Pemerintah tentang Perkawinan NJ menjawab tidak tahu mengenai hukum perkawinan. NJ ketika menikah walaupun masih dibaah umur tetapi dilakukan secara resmi (didaftarkan/dicatat di KUA). Ketika sudah mengetahui tentang aturan-aturan menikah yang ada dalam UU Perkawinan dan Peraturan Pemerintah tentang Perkawinan, khususnya batas usia perkawinan, maka jawabannya pernikahannya terus dilaksanakan namun mengikuti arahan dari KUA. Menurut NJ karena tidak terdapat sanksi yang jelas dalam undang-undang perkawinan atau Undang-undang lainnya terkait menikah dibawah umur maka masyarakat termasuk dirinya sendiri tidak takut ketika melanggranya
, kecuali ada sanksi yang berat pasti dirinya akan merasa takut.

Melalui hasil wawancara dengan informan yaitu Komarudin dan dan Aji Koro dari petugas Pegawai Pencatat Nikah (P2N) dari Desa Pamengkang memperoleh kesimpulan bahwa banyak alasan yang melatar belakangi masyarakat Desa Pamengkang, yang melakukan perkawinan dibawah umur diantaranya adalah:

1) faktor adat atau kebiasaan yang turun temurun dilakukan oleh keluarganya atau pada masyarakat setempat melaksanakan perkawinan dibawah umur,

2) faktor pengetahuan dan pemahaman yang kurang terhadap resiko perkawinan dibawah umur,

3) kekhawatiran orang tua mengenai pergaulan anak muda zaman sekarang,

4) faktor ekonomi yakni terlilit kemiskinan,

5) ada pula yang disebabkan karena takut tidak laku, dan lain sebagainya tanpa menimbang dan memikirkan bagaimana dampak dari perkawinan dibawah umur terhadap hak anak dan pendidikan.

Inilah yang menjadi perhatian utama ketika perkawinan dibawah umur dianggap suatu tradisi yang dilakukan 
secara turun temurun, karena sanksi sosial yang akan didapat hanya sebatas cemoohan dari masyarakat sekitar.

Jadi tingkat kesadaran hukum masyarakat terhadap mengenai UndangUndang Perkawinan, pada indikator pengetahuan hukum, pemahaman hukum, sikap hukum dan perilaku hukum, di Desa Pamengkang masih rendah. Rendahnya kesadaran hukum tersebut dipengaruhi oleh warga masyarakat Desa Pamengkang yang tidak mematuhi aturan-aturan yang ada dalam Undang-Undang Perkawinan.

Menurut Soerjono Soekanto (2016:160) dan Otje Salman (2010:43), hakikat kepatuhan hukum memiliki 3 (tiga) faktor yang menyebabkan warga masyarakat mematuhi hukum, antara lain:

a) Compliance, bentuk kepatuhan hukum masyarakat yang disebabkan karena adanya sanksi bagi pelanggar aturan tersebut, sehingga tujuan dari kepatuhan hanya untuk terhindar dari sanksi hukum yang ada.

b) Identification, bentuk kepatuhan hukum dimasyarakat yang disebabkan karena untuk mempertahankan hubungan yang menyenangkan dengan orang atau kelompok lain.

c) Internalization, bentuk kepatuhan hukum masyarakat dikarenakan masyarakat mengetahui tujuan dan fungsi dari kaidah hukum tersebut, sehingga menyebabkan masyarakat patuh kepada peraturan tersebut.

Dengan mengetahui ketiga jenis ketaatan ini maka kita dapat mengidentifikasi seberapa efektifnya suatu peraturan perundang-undangan. Dari hasil temuan penelitian, Peneliti akan menganalisis apakah dari temuan tersebut bisa untuk menjawab rumusan masalah dalam penelitian ini, yang pertama yaitu tentang kesadaran dan kepatuhan hukum masyarakat terhadap perkawinan dibawah umur di Desa Pamengkang, Kecamatan Kramatwatu, Kabupaten Serang.

Kesadaran hukum masyarakat terhadap perkawinan anak dibawah umur dapat timbul karena pengetahuan sekitar maupun lingkungan dimana mereka tinggal. Misalnya pada masyarakat perkotaan, sebagian besar masyarakat perkotaan lebih memilih untuk meneruskan pendidikannya ke tingkat yang lebih tinggi demi meraih karier yang lebih baik. Karena lingkungan sekitar sangat berpengaruh terhadap kemajuan pemikiran seseorang pada umumnya makin maju dan modern masyarakat tersebut, semakin banyak pula pengetahuan hukum yang ia mengerti.

Dan akan berbeda dengan yang ada di dalam masyarakat di wilayah 
pedesaan yang belum mengedepankan pendidikan demi meraih masa depan seseorang. Umumnya mereka mementingkan pekerjaan dari pada pendidikan. Walaupun hanya bekerja sebagai buruh kasar, mereka tetap lebih mementingkan pekerjaanya. Pendidikan tinggi bukanlah menjadi prioritas utama bagi masyarakat pedesaan yang mereka belum menyadari bahwa perkembangan zaman yang semakin hari semakin maju.

Berdasarkan hasil penelitian, masih banyak warga masyarakat desa Pamengkang yang tidak atau belum mengetahui Undang-Undang Perkawinan karena berbagai alasan yang diungkapkan oleh masyarakat. Diantaranya, kurangnya sosialisasi oleh Pemerintah setempat (Dinas terkait) mengenai hukum/Undang-Undang Perkawinan di setiap kampung. Ada pula yang mengatakan bahwa pengetahuan/pemahaman terhadap Undang-Undang Perkawinan belum terlalu penting bagi masyarakat (kecuali yang mau menikah). Sebagian masyarakat yang mengetahui hukum Undang-Undang Perkawinan pada umumnya adalah yang telah berstatus kawin atau menjelang dilangsungkannya perkawinan (calon pengantin). Selain itu, kurangnnya pengetahuan mengenai Undang-Undang
Perkawinan terjadi karena masyarakat yang sebagian besar tinggal di pedesaan, pendidikan mereka yang cukup rendah dan kurangnya kepedulian terhadap hukum positif (hukum yang berlaku di suatu Negara saat itu), membuat wawasan hukum masyarakat menjadi kurang luas. Namun, disamping tidak memiliki pengetahuan terhadap hukum positif, masyarakat patuh akan hukum tidak tertulis, yaitu seperti hukum adat atau tradisi di lingkungan mereka tinggal, hukum agama dan keyakinan yang dianut oleh masyarakat dan normanorma yang hidup di lingkungannya baik norma agama ataupun norma adat istiadat.

Paradigma yang berkembang pada masyarakat di Desa Pamengkang masih beranggapan bahwa perkawinan anak dibawah umur adalah suatu kewajaran yang tidak bertentangan dengan Undang-undang Perkawinan. Ada beberapa alasan di dalam hal ini yaitu: karena faktor ekonomi keluarga, ia menganggap bahwa seorang yang telah melakukan perkawinan, orang tua sudah tidak mempunyai kewajiban untuk memberikan nafkah kepada anak tersebut. Sehingga dapat meringankan beban orang tua yang hidup dengan standar ekonomi yang pas-pasan. Oleh karena itu ia menyetujui dengan adanya 
perkawinan anak dibawah umur tanpa memikirkan resiko yang ditimbulkan. Kemudian ada yang menyetujui adanya perkawinan anak dibawah umur karena sangat prihatin terhadap pergaulan remaja pada saat ini. Budaya berpacaran yang pada umumnya sudah melekat di kalangan remaja SMP dan SMA. Kondisi kenakalan remaja dan pergaulan yang cenderung (relatif) bebas di lingkungan mereka tergolong perlu diperbaiki dan diperhatikan oleh orang tua masing-masing, akan lebih baik jika dilakukan perkawinan supaya tidak terjadi lagi perzinahan yang marak terjadi di kalangan remaja yang sebagian besar telah berpacaran. Faktor pendidikan dan putus sekolah juga menjadi alasan mengapa masih terjadi perkawinan dibawah umur di desa Pamengkang.

Pengangguran juga menjadi salah satu sebab orang berlaku dan berbuat apa saja untuk mengisi waktu, termasuk menjalin hubungan dengan lawan jenis. Menjalin hubungan dengan lawan jenis mengakibatkan kemungkinan terjadinya hubungan seksual. Akibat berikutnya, timbulnya masalah yang muncul jika terjadi pernikahah di bawah umur. Dengan demikian, diharapkan sejak pendidikan usia dini dapat dijelaskan resiko pernikahan di bawah umur. Demikian juga upaya pencerahan paradigma orang tua amat dibutuhkan untuk memperkecil praktik pernikahan di bawah umur. Namun demikian tetap harus dicatat masih banyak variabel lain yang juga harus digarap dan dimaksimalkan agar berperan untuk menghapuskan praktik di bawah umur.

Kesadaran hukum masyarakat untuk tidak melakukan perkawinan dibawah umur dapat diketahui dengan indikator-indikator seperti pemahaman ataupun pengetahuan mengenai Undang-Undang Perkawinan yang disosialisasikan oleh pemerintah setempat. Sebagian masyarakat tidak menyetujui perkawinan dibawah umur dengan berbagai alasan yang diungkapkan. Kesadaran hukum juga bisa timbul karena faktor lingkungan dan teknologi yang semakin berkembang.

Namun pada umumnya orang berpendapat bahwa kesadaran hukum yang tinggi mengakibatkan para warga masyarakat mematuhi ketentuanketentuan hukum yang berlaku. Sebaliknya, apabila kesadaran hukum rendah, maka derajat kepatuhan hukum juga tidak tinggi. Dengan demikian, pendapat tersebut berkaitan dengan berfungsinya hukum dalam masyarakat atau efektifitas dari ketentuan-ketentuan hukum di dalam pelaksanaannya. Jadi 
kesadaran hukum menyangkut masalah apakah ketentuan hukum benar-benar berfungsi atau tidak dalam masyarakat.

Berdasarkan hasil penelitian yang dilakukan Peneliti, diperoleh hasil dan disimpulkan bahwa kesadaran hukum masyarakat di Desa Pamengkang, Kecamatan Kramatwatu, Kabupaten Serang dinilai belum sadar atau masih kurang tingkat kesadaran hukumnya terhadap hukum perkawinan dengan tidak melakukan perkawinan dibawah umur. Sesuai dengan indikatorindikator kesadaran hukum yang meliputi pengetahuan hukum, pemahaman hukum, sikap hukum dan pola perilaku terhadap hukum .

Apabila seseorang hanya mengetahui hukum, maka dapat dikatakan bahwa tingkat kesadaran hukum masih rendah, kalau dia telah berperilaku sesuai dengan hukum, maka kesadaran hukumnya tinggi. Untuk meningkatkan kesadaran hukum diperlukan adanya pembinaan maupun penyuluhan-penyuluhan agar warga masyarakat benar-benar mengetahui atau mengerti kegunaan dan tujuan dari dibuatnya peraturan perundangundangan, sehingga masyarakat dengan suka rela mentaati dan mematuhi peraturan perundang-undangan atau yang disebut sadar hukum.
Faktor yang menyebabkan kurangnya kesadaran hukum masyarakat di Desa Pamengkang antara lain; 1) faktor tingkat pendidikan masyarakat yang masih rendah, 2) faktor kebiasaan masyarakat tidak patuh hukum, dan 3) faktor kurangnya sosialisasi tentang hukum di masyarakat.

\section{Peran dari Pegawai Pencatat Nikah (P2N) dan Kantor Urusan Agama} (KUA) Setempat dalam Meminimalisir Perkawinan dibawah Umur di Desa Pamengkang.

Dalam upaya meningkatkan kesadaran hukum masyarakat Desa Pamengkang terhadap perkawinan dibawah umur ditinjau dari UndangUndang No. 16 tahun 2019 tentang Perubahan Undang-Undang No. 1 tahun 1974 tentang Perkawinan karena di desa Pamengkang pada saat ini masih ada yang melangsungkan perkawinan dibawah umur.

Menurut bapak Farid Hafid selaku Kepala KUA Kecamatan Kramatwatu mengenai Perkawinan dibawah umur, menurut keterangan beliau Pernikahan dibawah umur sampai saat ini di wilayah kerja nya yaitu Kecamatan Kramatwatu termasuk didalamnya desa Pamengkang, masih ada beberapa masyarakat yang melakukan. Sejauh ini upaya yang 
dilakukan oleh Farid Hafid selaku Kepala KUA Kecamatan Kramatwatu ketika ada masyarakat di wilayahnya yang mendaftarkan pernikahan tapi dengan calon mempelai salah satunya atau keduanya masih dibawah umur, maka yang dilakukannya adalah menolak untuk memberi surat pengantar atau membiarkan saja. Farid Hafid mengatakan bahwa pihak KUA Kecamatan Kramatwatu akan menolak jika ada pasangan yang akan menikah usia nya belum mencapai batasan usia yang ditentukan oleh Undang-undang Perkawinan, namun jika kedua mempelai memaksakan diri untuk melangsungkan pernikahan dibawah umur tersebut, pihak KUA hanya mengarahkannya untuk mengajukan permohonan izin dispensasi nikah/kawin ke Pengadilan Agama setempat (ket: calon mempelai yang mendaftarkan untuk menikah di KUA berarti mereka adalah beragama Islam, maka ketika ada sengketa/permasalahan dalam pernikahannya maka penyelesaiannya adalah di Pengadilan Agama). Jika Surat Penetapan Izin Nikah dari Pengadilan Agama sudah keluar, maka pihak KUA akan melaksanakan tugasnya untuk mencatat pernikahan tersebut.

Pihak KUA Kecamatan Kramatwatu juga mendata masyarakat yang melangsungkan perkawinan dibawah umur, tetapi yang dicatat hanya jika prosedur sudah dipenuhi oleh kedua mempelai termasuk surat izin dispensasi kawin dari Pengadilan Agama. Terkait pencegahan untuk mengatasi hal tersebut pihak dari KUA tersebut sudah mengadakan penyuluhan sosial ke setiap kelurahan yang ada di Kecamatan Kramatwatu untuk tidak melangsungkan pernikahan di bawah umur. Karena pernikahan dibawah umur itu sangat berpengaruh terhadap fisik dan psikis seseorang bahkan pola fikir pasangan suami istri remaja (bawah umur) yang terbilang masih labil.

Sedangkan berdasarkan hasil wawancara dengan Komarudin selaku P2N Desa Pamengkang mengenai peran P2N dalam meningkatkan kesadaran hukum tentang usia perkawinan adalah sebagai berikut.

Menurut Komarudin alasan remaja (di bawah umur) melakukan perkawinan adalah karena mereka sudah merasa dewasa, suka sama suka dan untuk mengurangi beban orang tua, sama halnya dari faktor orang tua pun mengikuti dikarenakan pergaulan remaja pada saat ini sangat miris, orang tua khawatir anaknya mengikuti pergaulan bebas seperti yang sekarang sering terjadi. Dan dilihat dari faktor pendidikan pun mempengaruhi terjadinya perkawinan dibawah umur karena wawasan dan pengetahuan mereka masih terbatas tentang Undang-Undang Perkawinan. Semua masyarakat Desa 
Pamengkang yang melangsungkan perkawinan dibawah umur dilakukan secara resmi (dicatat di KUA) jika sudah memenuhi prosedur yang ditentukan oleh KUA berdasarkan Undang-Undang Perkawinan, yaitu harus ada izin dispensasi kawin/nikah dari Pengadilan Agama. Mengenai tingkat kesadaran maupun kepatuhan hukum masyarakat Desa Pamengkang, menurut Komarudin masih kurang sadar hukum karena masyarakat tersebut masih awam hukum khususnya Undang-Undang Perkawinan. Awamnya pemahaman hukum masyarakatdi Desa Pamengkang dikarenakan tingkat pendidikan yang masih rendah, mayoritas masyarakat hanya lulusan SMP.

Mengenai bentuk pencegahan untuk pernikahan dibawah umur yang dilakukan oleh P2N Desa Pamengkang, menurut Komarudin, pihaknya tidak mempersulit proses pendaftaran nikahnya, dikarenakan sudah ada Undang-undang yang mengatur tentang Pernikahan dibawah umur, yaitu izin dispensasi menikah dari Pengadilan Agama.

Peran P2N selain menjalankan tugas pokok penghulu yakni melakukan perencanaan kegiatan penghuluan, pengawasan pencatatan dan pelaksanaan pelayanan nikah/rujuk, penasihatan dan konsultasi nikah/rujuk, pelayanan fatwa hukum munakahat dan bimbingan muamalah, pembinaan keluarga sakinah, serta pemantauan dan evaluasi kegiatan kepenghuluan.

Ada beberapa upaya yang dilakukan oleh Komarudin selaku P2N di Desa Pamengkang selain dalam penyelesaian sengketa kasus perkawinan dibawah umur. Dalam menanggulangi perkawinan dibawah umur diantaranya: memberikan bimbingan kepada calon mempelai yang hendak kawin, memberikan penyuluhan kepada para jamaah pengajian (majelis taklim) tentang betapa pentingnya perkawinan jika didahului dengan persiapan fisik dan mental yang kokoh.

Sedangkan upaya yang dilakukan KUA untuk meningkatkan Kesadaran Hukum Masyarakat di Desa Pamengkang mengenai hukum perkawinan, dan pencegahan perkawinan dibawah umur adalah dengan mengadakan penyuluhan atau sosialisasi ke setiap desa yang ada di Kecamatan Kramatwatu untuk tidak melakukan perkawinan dibawah umur khususnya untuk remaja. Karena kawin dibawah umur itu sangat berpengaruh terhadap fisik dan psikis seseorang bahkan pola fikir yang terbilang masih labil. Mengenai hubungan/kemitraan kerja antara KUA dengan $\mathrm{P} 2 \mathrm{~N}$ hanya sebatas jika pegawai dari KUA tidak memenuhi kebutuhan masyarakat yang melakukan perkawinan maka KUA meminta P2N untuk menghadiri perkawinan tersebut. Tidak semua desa yang ada di Kecamatan 
Kramatwatu mempunyai P2N, dan salah satu desa yang memiliki P2N adalah Desa Pamengkang.

Masyarakat di Desa Pamengkang, Kecamatan Kramatwatu, Kabupaten Serang belum sepenuhnya mematuhi Undang-Undang Perkawinan secara konsekwen, dimana masyarakat masih banyak yang melakukan perkawinan dibawah umur. Upaya-upaya yang dilakukan P2N Desa Pamengkang dan KUA Kecamatan Kramatwatu dalam meminimalisir terjadinya perkawinan dibawah umur di Desa Pamengkang antara lain:

a. Melakukan sosialisasi UndangUndang Perkawinan baik melalui kegiatan formal maupun non formal, seperti acara perkawinan, dan penyuluhan kursus calon pengantin,

b. Memberikan penyuluhan tentang batasan usia perkawinan kepada masyarakat, khususnya kepada calon pengantin melalui kerjasama dengan $\mathrm{P} 2 \mathrm{~N}$, aparat desa, tokoh masyarakat dan tokoh agama yang secara langsung dapat berkomunikasi dengan masyarakat,

c. Memberikan penyuluhan kepada masyarakat akan resiko pernikahan dibawah umur baik fisik maupun mental jika melakukan perkawinan dibawah umur, karena betapa pentingnya perkawinan harus didahului dengan persiapan fisik dan mental yang kokoh.

Berdasarkan observasi dan hasil wawancara dengan informan peneliti berkesimpulan bahwa perkawinan dibawah umur yang terjadi di Desa Pamengkang merupakan perkawinan yang tidak ideal dan melanggar atau tidak sesuai dengan batasan umur yang ditentukan oleh Undang-Undang Perkawinan.

Maka menurut peneliti sudah seharusnya P2N dan KUA ketika ada masyarakat yang akan mendaftarkan/mencatatkan perkawinannya dimana perkawinan tersebut calon mempelainya baik salah satunya atau keduanya masih dibawah umur (dibawah 19 tahun) dipersulit bahkan ditolak untuk dicatat. Sebab ditinjau dari segi fisik (reproduksi) dan psikis anak dibawah umur tidak baik dan belum siap untuk kawin dengan tanggung jawab yang berat dan komitmen yang tinggi. Bisa dibayangkan manakala kedua calon mempelai dengan karakter psikis egosentris menyatu dalam satu pasangan hidup, terlebih lagi manakala terjadi permasalahan dalam rumah tangga tersebut, hal ini yang sering menimbulkan perceraian karena tidak bisa menyelesaikan permasalahan yang terjadi.

\section{KESIMPULAN}

1. Perkawinan dibawah umur di Desa Pamengkang, Kecamatan Kramatwatu, 
Kabupaten Serang masih terjadi yang disebabkan beberapa faktor-faktor yaitu, faktor tradisi atau kebiasaan masyarakat setempat, kekhawatiran terhadap gunjingan masyarakat ketika anak (perempuan) nya menjadi perawan tua (belum juga mendapatkan jodoh) jika tidak dikawinkan pada usia muda, faktor ekonomi yang lemah, pengangguran, pendidikan rendah dan putus sekolah. Hal tersebut menunjukkan bahwa Masyarakat Desa Pamengkang belum sadar hukum atau tingkat kesadaran dan kepatuhan hukumnya masih rendah khususnya kesadaran terhadap batasan umur menikah yang diatur dslsm UndangUndang Perkawinan dengan tidak melakukan perkawinan dibawah umur. Faktor yang turut mempengaruhi kurangnya kesadaran dan kepatuhan hukum masyarakat Desa Pamengkang terhadap Undang-Undang Perkawinan dan tidak melakukan perkawinan dibawah umur adalah disebabkan faktor pendidikan, kebiasaan tidak patuh hukum dan kurangnya sosialisasi dan penyuluhan hukum Undang-Undang Perkawinan dan resiko perkawinan dibawah umur oleh Pemerintah setempat (KUA dan P2N).

2. Peran dari Pegawai Pencatat Nikah (P2N) Desa Pamengkang dan Kantor Urusan Agama (KUA) setempat dalam meminimalisir perkawinan dibawah umur sangatlah berperan, khususnya dalam menumbuhkan kesadaran kepada masyarakat dan calon pengantin mengenai batasan usia perkawinan yang sesuai dengan Undang-Undang Perkawinan. Dengan melakukan sosialisasi, penyuluhan, dan pembinaan terkait pemahaman calon pengantin mengenai UndangUndang Perkawinan dalam rangka mewujudkan keluarga yang ideal dan sejahtera. Apabila masyarakat mengetahui dan memahami UndangUndang Perkawinan maka kesadaran dan kepatuhan hukum masyarakat terhadap aturan batasan usia perkawinan akan semakin berkurang dimasyarakat.

\section{DAFTAR PUSTAKA}

\section{a. Buku}

Ibnu Radwan Siddiq T, (2019) Hukum Perdata Islam Di Indonesia, Medan, Fakultas Syariah dan Hukum Universitas Islam Negeri Suamatera Utara.

Moleong, Lexy J. (2014). Metode Penelitian Kualitatif. Bandung : PT. Remaja Rosada Karya.

Neng Djubaidah, 2012, Pencatatan Perkawinan dan Perkawinan Tidak Dicatat; Menurut Hukum Tertulis di Indonesia dan Hukum Islam, Jakarta, Sinar Grafika. 
Saebeni, Ahmad Beni. (2006), Sosiologi Hukum, Bandung. Pustaka Setia,

Salman, Otje. (2010). Filsafat Hukum (Perkembangan \& Dinamika Masalah). Bandung. PT .Refika Aditama

Soekanto, Soerjono. (2017). PokokPokok Sosiologi Hukum. Jakarta : CV. Rajawali.

Sugiyono. (2016). Metode Penelitian Kuantitaf, Kualitatif, dan $R \& D$. Bandung :Alfabeta.

Tim Penyusun, (2018) Himpunan Peraturan Perundang-undangan Republik Indonesia Undangundang Perlindungan Anak, Yogyakarta: Laksana.

\section{b. Jurnal Ilmiah \& Skripsi}

Ahmad Bachroni dkk (2019). Dispensasi Kawin Dalam Tinjauan Undang-Undang Nomor 23 Tahun 2002 Juncto Undang-Undang Nomor 35 Tahun $2014 \quad$ Tentang Perlindungan Anak. Jurnal Transparansi Hukum. Vol 2, Nomor 2.

Ahmad Tholabi Kharlie. (2008).

Kesadaran Hukum Masyarakat Lebak, Banten (studi atas implementasi UU No. 1 Tahun 1974 Tentang Perkawinan). Jurnal AlQalam. Vol 25.

Ani Yumarni dan Endeh Suhartini. (2019). Perkawinan Bawah Umur dan Potensi Perceraian. Jurnal Hukum Ius Quia Iustum. Vol 26, No.1
Sebagai Bentuk Kekerasan Menurut UU No. 23 Tahun 2004 (Kajian Penelantaran Rumah Tangga Sebagai Penyebab Terbesar Perempuan Mengajukan Gugatan Cerai Di Pengadilan Agama Serang). Jurnal Pendidikan Pancasila dan Kewarganegaraan. Vol 1.

Hotmartua Nasution, (2019), Pembaharuan Hukum Keluarga Islam Tentang Usia Perkawinan Di Indonesia (Studi Atas Undang-Undang Nomor 16 Tahun 2019 Tentang Perubahan UndangUndang Nomor 1 Tahun 1974 Tentang Perkawinan, Medan. Skripsi, Fakultas Syari'ah Dan Hukum Universitas Islam Negeri Sumatera Utara.

\section{c. Peraturan Perundang-undangan}

Undang-Undang Nomor 1 Tahun 1974 Tentang Perkawinan

Undang-Undang Republik Indonesia Nomor 16 Tahun 2019 Tentang Perubahan Atas Undang-Undang Nomor 1 Tahun 1974 Tentang Perkawinan.

$\begin{array}{ccr}\text { Peraturan } & \text { Pemerintah } & \text { Nomor } 9 \\ \text { Tahun } & 1975 & \text { Tentang } \\ \text { Pelaksanaan } & \text { Undang-Undang } \\ \text { Perkawinan. } & & \end{array}$
Anton
Aulawi.
(2018).
Penelantaran Rumah Tangga 